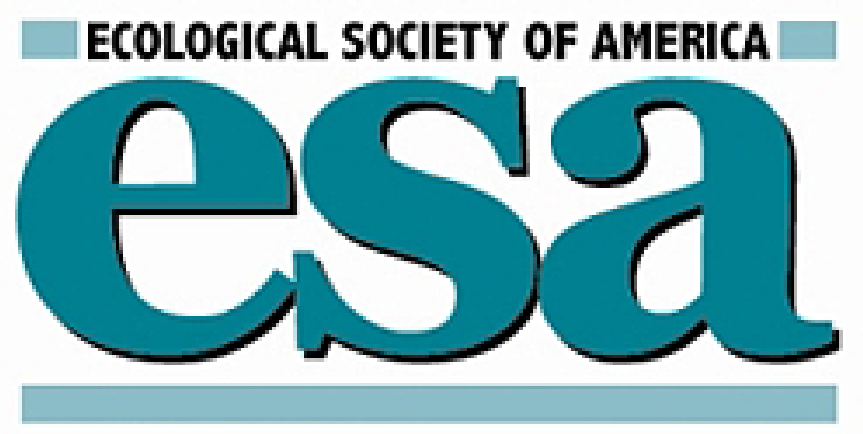

Oceanographic Habitat of an Endangered Mediterranean Procellariiform: Implications for Marine Protected Areas

Author(s): Maite Louzao, K. David Hyrenbach, José Manuel Arcos, Pere Abelló, Luis Gil de Sola and Daniel Oro

Source: Ecological Applications, Vol. 16, No. 5 (Oct., 2006), pp. 1683-1695

Published by: Ecological Society of America

Stable URL: http://www.jstor.org/stable/40061742

Accessed: 30/06/2014 07:06

Your use of the JSTOR archive indicates your acceptance of the Terms \& Conditions of Use, available at http://www.jstor.org/page/info/about/policies/terms.jsp

JSTOR is a not-for-profit service that helps scholars, researchers, and students discover, use, and build upon a wide range of content in a trusted digital archive. We use information technology and tools to increase productivity and facilitate new forms of scholarship. For more information about JSTOR, please contact support@jstor.org. 


\title{
OCEANOGRAPHIC HABITAT OF AN ENDANGERED MEDITERRANEAN PROCELLARIIFORM: IMPLICATIONS FOR MARINE PROTECTED AREAS
}

\author{
Maite Louzao, ${ }^{1}$ K. David Hyrenbach, ${ }^{2}$ José Manuel Arcos, ${ }^{3,4}$ Pere Abelló, ${ }^{5}$ Luis Gil de Sola, ${ }^{6}$ \\ AND DANIEL Oro ${ }^{1}$ \\ 'IMEDEA (CSIC-UIB), Miquel Marquès 21,07190 Esporles, Mallorca, Spain \\ ${ }^{2}$ Duke University Marine Laboratory, 135 Duke Marine Lab Road, Beaufort, North Carolina 28516 USA \\ ${ }^{3} I B L S$, Graham Kerr Building, University of Glasgow, G128QQ Glasgow, Scotland, UK \\ ${ }^{4}$ SEO/BirdLife, Avenida Mistral 61, 6-1,08015 Barcelona, Spain \\ ${ }^{5}$ Institut de Ciències del Mar, CMIMA (CSIC), Passeig Marítim de la Barceloneta 37-49, 08003 Barcelona, Spain \\ ${ }^{6}$ Centro Oceanográfico de Fuengirola, IEO, Muelle Pesquero, 29640 Fuengirola, Málaga, Spain
}

\begin{abstract}
Marine protected areas (MPAs) require ecologically meaningful designs capable of taking into account the particularities of the species under consideration, the dynamic nature of the marine environment, and the multiplicity of anthropogenic impacts. MPAs have been most often designated to protect benthic habitats and their biota. Increasingly, there is a need to account for highly mobile pelagic taxa, such as marine birds, mammals and turtles, and their oceanic habitats. For breeding seabirds foraging from a central place, particular attention should be paid to distant foraging grounds and movement corridors, which can often extend to hundreds of kilometers from breeding colonies. We assessed the habitat use by the most threatened Mediterranean seabird, the Balearic Shearwater, Puffinus mauretanicus, using vessel-based surveys during the chick-rearing period (May-June). We used a hierarchical modeling approach to identify those environmental variables that most accurately reflected the oceanographic habitat of this species by (1) delineating its foraging range using presence/ absence data and (2) identifying important foraging grounds where it concentrates in dense aggregations. The foraging range comprised the frontal systems along the eastern Iberian continental shelf waters (depth $<200 \mathrm{~m}$ ) and areas close to the breeding colonies in the Balearic Islands. Shearwaters aggregated in productive shelf areas with elevated chlorophyll $a$ concentrations. Following the model of a core-buffer MPA, we envisioned those areas of dense aggregation (i.e., the area of influence of the Ebro River discharge and Cape La Nao regions) as the core regions deserving elevated protection and more stringent management. More diffuse protective measures would be applied within the larger buffer region, delineated by the foraging range of the species. Marine zoning measures can greatly benefit the conservation of the Balearic Shearwater and other far-ranging seabirds by extending protective measures beyond their breeding colonies during both the breeding and nonbreeding seasons.
\end{abstract}

Key words: Balearic Shearwater; conservation; habitat modeling; MPAs; oceanography; Puffinus mauretanicus; remote sensing; ROC curves; seabird-fishery interactions.

\section{INTRODUCTION}

Spatially explicit conservation measures are increasingly taking the central stage of fisheries management and marine conservation strategies (Pikitch et al. 2004, Norse et al. 2005). Networks of marine protected areas (hereafter MPAs) are being used to manage fisheries and to protect threatened species and marine habitats around the globe (Houde 2001, Roberts et al. 2001, Halpern 2003). Although most effort has been focused on sessile and sedentary ecosystems and organisms (e.g., coral reefs, mangroves, reef fishes), there is an increasing interest to extend the application of MPAs to encompass

Manuscript received 5 January 2006; accepted 24 February 2006; final version received 31 March 2006. Corresponding Editor: P. K. Dayton.

${ }^{7}$ E-mail: m.louzao@uib.es highly mobile species (e.g., marine mammals, birds, and turtles). These far-ranging marine vertebrates are susceptible to multiple anthropogenic impacts (e.g., fisheries bycatch, oil spills) within their foraging grounds and migratory routes (Anderson et al. 2003, Hooker and Gerber 2004, James et al. 2005). At the same time, because these species are often associated with dynamic oceanographic habitat features, an understanding of these wildlife-habitat associations is critical for evaluating the feasibility and design of pelagic MPAs (Hooker et al. 1999, Hyrenbach et al. 2000, Norse et al. 2005). Thus, marine zoning strategies for highly mobile marine organisms will require new ecologically meaningful approaches in tune with their life history and the dynamic nature of the pelagic environment (Hyrenbach et al. 2000, Planes et al. 2000, Gerber et al. 2005).

In the European Union (EU), Council Directive 79/ $409 /$ EEC (EEC 1979) for the protection of wild birds 
(Birds Directive) and Council Directive 92/43/EEC (EEC 1992) for the conservation of natural habitats and wild fauna and flora (Habitats Directive) established the foundation for the creation of a network of terrestrial and marine protected areas to conserve natural habitats and wild flora and fauna. The Natura 2000 network envisions Special Protection Areas (SPAs, under the Bird Directive) and Special Areas of Conservation (SACs, under the Habitat Directive) to protect those species and habitats in danger of disappearing, while higher protective measures are pending. Within this framework, several studies have quantified the abundance and distribution of cetaceans and sea turtles in the Western Mediterranean (Bearzi et al. 2003, De Segura et al. 2003, Cañadas et al. 2005, Cardona et al. 2005). While little attention has been paid to seabirds in the past, a regional strategy is currently underway for important bird area (IBA) delineation in the Western Mediterranean. This program, under the auspices of BirdLife International, seeks to identify, document, and conserve sites that are key for the longterm viability of bird populations (SPEA-SEO/BirdLife 2005). In the EU, IBAs form the scientific basis and the ornithological reference for the creation of a network of Special Protection Areas (SPAs) under the Birds Directive (Williams et al. 2005). IBA is a nongovernment, globally applicable construct and carries no legal obligation, whereas the SPA concept is a legally binding obligation on EU member states.

In this paper, we assess habitat use by the most threatened Mediterranean seabird, the Balearic Shearwater, Puffinus mauretanicus, as a priority in the design of marine zoning strategies to protect seabirds in this biogeographic region. This shearwater is currently listed as Critically Endangered on the IUNC Red List (Arcos and Oro 2004, Baillie et al. 2004) due to its restricted breeding range (constrained to the Balearic Islands) and small ( $\sim 2000$ breeding pairs; Ruiz and Martí 2004) and declining (7.4\% decrease per year; Oro et al. 2004) population size. Population models predict a decrease of 98\% within 54 years (three generations), with a mean predicted time of extinction of 40.4 years (Oro et al. 2004). The species is known to feed extensively on shoals of small pelagic fish, also consuming considerable amounts of fishery discards (Arcos and Oro 2002). Nevertheless, its ecology at sea is still poorly understood (Arcos et al. 2000). In accordance, while much conservation effort is being focused on the breeding colonies, the potential threats at sea (e.g., bioaccumulation of pollutants, fisheries bycatch, and oil spills) have been largely overlooked (Arcos and Oro 2004).

We characterized the oceanographic habitat of the Balearic Shearwater in the Western Mediterranean during the breeding season (May-June). Our objective was to assess whether marine zoning strategies could protect the foraging grounds and movement corridors of this endangered species during this critical period of its annual cycle. Following the Natura 2000 directive, we regarded the habitat as "an environment defined by specific abiotic and biotic factors, in which the species lives at any stage of its biological cycle." Thus, our habitat-use analysis considered both abiotic (e.g., bathymetric and hydrographic features) and biotic (e.g., ocean productivity patterns) features. We used a hierarchical modeling approach to identify those environmental variables that most accurately reflected the habitat of the Balearic Shearwater by (1) delineating the range of the species using presence/absence data and (2) identifying important foraging areas where the species concentrates in dense aggregations. Within this framework, we make recommendations for the implementation of marine protected areas (MPAs) to protect this critically endangered western Mediterranean seabird during the chick-rearing season.

\section{METHODS \\ Study area}

We studied the distribution and oceanographic habitat of the Balearic Shearwater in the Western Mediterranean during the 1999, 2000, and 2002 chickrearing periods (May-June). Surveys were conducted onboard the R/V "Cornide de Saavedra," during the annual MEDITS (Mediterranean International Trawl Survey) surveys along the Mediterranean coast of the Iberian Peninsula (Bertrand et al. 2002), from the Strait of Gibraltar in the southwest to Cape Creus in the northeast (Fig.1).

The study area encompassed $2134 \mathrm{~km}^{2}$, with $72 \%$ of the area corresponding to the continental shelf (depth $<200 \mathrm{~m}$ ) and the rest covering the continental slope down to a depth of $1930 \mathrm{~m}$ (Fig. 1). Overall, the continental shelf is very narrow $(\sim 3 \mathrm{~km})$ in the Alboran Sea and the Vera Gulf, and widens to the north, reaching a width of up to $70 \mathrm{~km}$ in the Ebro DeltaColumbretes area.

\section{Oceanographic context}

In the Western Mediterranean, ocean productivity is notoriously heterogeneous, being influenced by marine currents and the input of freshwater run-off, which deliver large amounts of nutrients and fertilize the coastal waters (Arnau et al. 2004). The advection of Atlantic Ocean water, which enters through the Strait of Gibraltar, forms a quasi-permanent-anticyclonic (clockwise) gyre in the Alboran Sea (Millot 1999). Farther east, the "Almería-Oran Jet" flows from the Iberian coast towards Algeria, giving rise to eddies (Millot 1999). These hydrographic processes promote nutrient enrichment of surface waters in this area (Estrada 1996). Farther north, the Northern Current (or "LiguroProvenço-Catalan" Current), which originates in the east of the Ligurian Sea and flows south of the Eivissa Channel along the continental slope, transports rich nutrient waters southwards (Millot 1999, Arnau et al. 2004). In the Ebro Delta area, strong and cold winds from the north and northwest lead to enhanced mixing, 


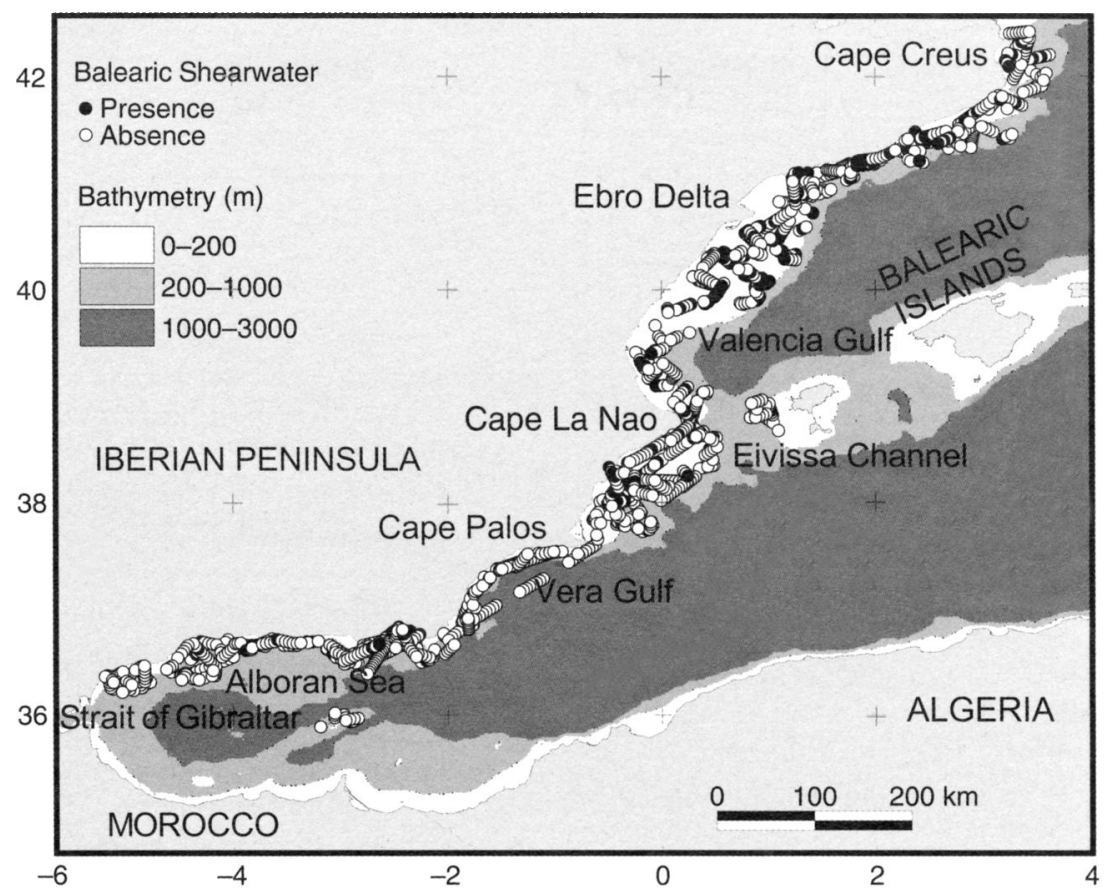

Fig. 1. Map of the study area showing all sample units (10 min bins; 1999-2002). Geographic references mentioned in the text are indicated.

the upwelling of nutrients, and the consequent increase of plankton production (Estrada 1996, Salat 1996). A permanent front with strong salinity gradients, known to limit the seaward dispersion of the larvae of coastal and shelf species (i.e., fish, crustaceans), retains this high localized productivity near the coast (Font et al. 1988, Sabatés 1996, Abelló and Guerao 1999). This productive region represents a major fish spawning area, especially for small pelagic species like anchovy and sardine (Sabatés 1996, Salat 1996, Agostini and Bakun 2002), and supports one of the most important fishing fleets of the western Mediterranean (Demestre et al. 1988, Estrada 1996, Salat 1996). Additionally, submarine canyons north of Barcelona are also thought to enhance ocean productivity (Palanques et al. 2005).

\section{At-sea surveys}

All observations were made by the same observer ( $\mathrm{J}$. M. Arcos) during 1999, 2000, and 2002 using standardized strip-transect techniques (Tasker et al. 1984) adapted to match the specific conditions of the study area. A 300-m strip-width transect band was used, with the observer surveying both sides of the vessel (i.e., 600$\mathrm{m}$ band) only when conditions (visibility and wind) were appropriate. The width of the band was checked periodically using a range-finder (Heinemann 1981). Snapshot counts were used to census flying birds (Tasker et al. 1984). All Balearic Shearwaters observed within the survey transect were recorded. Additionally, the number of trawlers sighted within a three-nautical-mile $(5.58 \mathrm{~km})$ band were also recorded, to account for the influence of fishing discards on the distribution of the species. The shearwater and vessel sightings were summed up into 10-minute survey bins.

\section{Environmental variables}

Sea surface temperature (SST, hereafter) and chlorophyll $a$ concentration (chl $a$, hereafter) are useful proxies of water mass distributions, frontal systems, and ocean productivity domains (e.g., LeFevre 1986, Longhurst 1998), and have been previously used to characterize the oceanographic habitats of seabirds (e.g., Spear et al. 2001, Hyrenbach et al. 2002). We relied on remotelysensed environmental information, which is available at a variety of spatial and temporal resolutions, to quantify SST and chl $a$ conditions during our seabird surveys. We used the 8-day composites of 9-km pixel data because the imagery at the finer daily temporal resolution was obstructed by cloud cover to a great extent.

We used nighttime Pathfinder 4.1 SST imagery from the Advanced Very High Resolution Radiometer (AVHRR) to quantify water temperature during our surveys (available online). ${ }^{8}$ We derived the chl $a$ concentrations from Sea-viewing Wide Field-of-view Sensor (SeaWiFS) imagery (available online). ${ }^{9}$ We discarded any values beyond the range of SeaWiFS validation $\left(0.05-50 \mathrm{mg} / \mathrm{m}^{3}\right.$; Hooker and McClain 2000). We considered four different productivity regimes based

${ }^{8}$ 〈http://podaac.jpl.nasa.gov/pub/sea_surface_temperature/ avhrr/pathfinder/data_v4.1/ $>$

${ }^{9}\langle$ http://seawifs.gsfc.nasa.gov/SEAWIFS.html〉 
on the chl $a$ values: oligotrophic (low nutrient, chl $a<$ $0.1 \mathrm{mg} / \mathrm{m}^{3}$ ); mesotrophic (intermediate nutrient, chl $a=$ $0.1-0.3 \mathrm{mg} / \mathrm{m}^{3}$ ), eutrophic (high nutrient, chl $a=0.3-1$ $\left.\mathrm{mg} / \mathrm{m}^{3}\right)$, and enriched waters (chl $\left.a>1 \mathrm{mg} / \mathrm{m}^{3}\right)(\mathrm{Kahru}$ and Mitchell 2000).

Because water depth influences seabird distributions, as indicated by the different communities that inhabit distinct coastal and pelagic domains (Schneider 1997), we included this variable in the habitat model. We obtained bathymetric data from NOAA's ETOPO fiveminute (spatial resolution of 7.5 and $8.2 \mathrm{~km}$ at $35^{\circ} \mathrm{N}$ and $42^{\circ} \mathrm{N}$ latitude, respectively) gridded elevation data set (NGDC 1998).

Because these three habitat variables, SST, chl $a$ concentration, and water depth, were not normally distributed, we used the median as a conservative statistic to express the central tendency of these variables within each 9-km cell grid (Zar 1999). In addition, we quantified the spatial gradients of these properties for each $9-\mathrm{km}$ grid cell. We calculated the proportional change (PC) in SST, chl $a$, and depth within a surrounding $3 \times 3$ pixel $(27 \times 27 \mathrm{~km})$ grid as follows: $\mathrm{PC}=[($ maximum value - minimum value $) 100] /(\max -$ imum value). This dimensionless metric expresses the magnitude of change in each habitat variable, scaled to the maximum value.

To account for the influence of colonies on the distribution of central-place-foraging seabirds at-sea during the breeding season, we included the distance from the centroid of each grid cell to the nearest breeding site (see Louzao et al. 2006 for colony locations). Finally, we also included the distance from each grid cell to the nearest shoreline in the model to account for additional potential onshore-offshore patterns.

\section{Data processing}

We explored shearwater habitat associations using the ArcView 3.2 Geographic Information Systems (GIS) software (1999), by merging the seabird distribution data with the environmental information. We first standardized the survey effort to account for differences in the area surveyed during each 10-min bins, due to varying cruising speeds and strip widths. We aggregated the survey bins into $9-\mathrm{km}$ grid cells $\left(81 \mathrm{~km}^{2}\right)$, at the same spatial scale of the remote sensing imagery, and recalculated the occurrence and density of shearwaters and trawlers for these grid cells. We repeated this process for each 8-day survey period, to match the temporal scale of the remote sensing imagery. Thus, whenever a grid cell was visited repeatedly in the course of the same cruise, it contributed a data point for each 8day period it was surveyed.

We then extracted the oceanographic variables (SST, chl $a$, depth) for each grid cell using the WIM 6.26 software (Kahru 2000). Because the median and gradient values for each grid cell were calculated within a surrounding $3 \times 3$ pixel $(27 \times 27 \mathrm{~km})$ neighborhood, the number of valid data points could range from 0 to 9 ; we rejected those grids cells with fewer than two valid data points. After standardization, we calculated the distance between the centroid of each grid cell and the nearest shearwater colony and shoreline using the ArcView 3.2 GIS.

\section{Data analysis}

Spatial autocorrelation.-Before undertaking the statistical analysis of the Balearic Shearwater distributions, we had to ensure that the observations were independent (i.e., the number of birds in any grid cell was not related to their distribution in adjacent grid cells). In clumped distributions, like seabird flocks, adjacent observations are often more similar than would be expected in randomly distributed data, revealing significant positive autocorrelation patterns (Schneider 1990, Sokal et al. 1998). Significant autocorrelation can cause the false rejection of the null hypothesis (Type I error), giving raise to spurious significant habitat relationships (Hurlbert 1984). We used the Moran's I coefficient to assess the spatial autocorrelation patterns in the seabird data. This index, developed to quantify spatial patterns for highly nonnormal distributions, ranges from -1 (negative autocorrelation) to +1 (positive autocorrelation), with null values being indicative of a lack of spatial structure (Sokal and Oden 1978).

We quantified the similarity of the Balearic Shearwater occurrence (presence/absence) and density (birds/ $100 \mathrm{~km}^{2}$ ) for all pairwise combinations of grid cells as a function of their spatial distance, and considered up to 15 spatial lags at $9-\mathrm{km}$ intervals $(0-135 \mathrm{~km})$ in any direction (i.e., assuming an isotropic spatial autocorrelation structure). We assessed the significance of the Moran's $I$ values using Monte Carlo randomization tests (Manly 1994). Both the Moran's I values and randomization tests were performed using the Rook Case V.1.6 software (Sawada 1999). Briefly, we performed 1500 permutations at each lag distance and contrasted the observed Moran's $I$ value with those calculated by the randomization procedures. The Bonferroni correction was used to account for multiple testing.

Model building.-We related shearwater occurrence (presence/absence) and density (when shearwaters were present) to 11 explanatory variables. We used eight environmental variables: median depth, depth gradient, distance to shoreline, distance to the closest colony, median SST, SST gradient, median chl $a$, and chl $a$ gradient. Due to unequal survey effort in each grid cell, we included survey effort $\left(\mathrm{km}^{2}\right)$ as a covariate in the analysis to account for potential biases. Also, we included the occurrence and density of trawlers because of the potential influence of fishery discards on shearwater distribution. Finally, we considered the effect of "year" to assess interannual variability in shearwater distribution and abundance during our study. 
TABLE 1. Bivariate Spearman rank $P$ values (above diagonal) and correlations between environmental variables (below diagonal) in the analyzed $9-\mathrm{km}$ grid cells $(n=567)$.

\begin{tabular}{|c|c|c|c|c|c|c|c|c|}
\hline Variable & $\begin{array}{l}\text { Distance to } \\
\text { shoreline }\end{array}$ & $\begin{array}{c}\text { Distance to } \\
\text { colony }\end{array}$ & $\begin{array}{l}\text { Median } \\
\text { depth }\end{array}$ & $\begin{array}{l}\text { Depth } \\
\text { gradient }\end{array}$ & $\begin{array}{c}\text { Median } \\
\text { chl } a\end{array}$ & $\begin{array}{l}\text { Chl } a \\
\text { gradient }\end{array}$ & $\begin{array}{l}\text { Median } \\
\text { SST }\end{array}$ & $\begin{array}{c}\text { SST } \\
\text { gradient }\end{array}$ \\
\hline Distance to shoreline & 1.000 & $<0.001$ & $<0.001$ & $<0.001$ & $<0.001$ & NS & NS & $<0.05$ \\
\hline Distance to colony & -0.271 & 1.000 & $<0.001$ & $<0.01$ & $<0.001$ & NS & $<0.001$ & $<0.01$ \\
\hline Median depth & 0.323 & 0.415 & 1.000 & $<0.001$ & $<0.05$ & $<0.05$ & $<0.001$ & $<0.001$ \\
\hline Depth gradient & -0.668 & 0.124 & -0.381 & 1.000 & $<0.001$ & NS & NS & $<0.001$ \\
\hline Median chl $a$ & -0.196 & 0.419 & -0.083 & 0.153 & 1.000 & $<0.001$ & $<0.001$ & $<0.001$ \\
\hline Chl $a$ gradient & 0.024 & -0.025 & -0.095 & 0.001 & 0.370 & 1.000 & $<0.01$ & NS \\
\hline Median SST & 0.057 & -0.384 & -0.178 & -0.017 & -0.462 & -0.122 & 1.000 & $<0.001$ \\
\hline SST gradient & 0.107 & 0.110 & 0.167 & -0.169 & 0.155 & 0.057 & -0.180 & 1.000 \\
\hline
\end{tabular}

Note: NS, nonsignificant.

Because the environmental conditions in the study area were cross-correlated (Table 1), we used multivariate statistics to assess the relative influence of each habitat variable on shearwater distribution. We used generalized linear models (GENMOD procedure; SAS Institute 2000), and adopted a hicrarchical modeling approach, where we first characterized the overall range of the species using occurrence (presence/absence) records from the entire data set. We built this model assuming a binomial distribution and using the logit-link function, and evaluated the goodness of fit using the Pearson's chi-square statistic (Crawley 1993). Then, after excluding those bins where shearwaters were absent, we quantified the areas of high aggregation using the continuously distributed density data using the identity link function.

We assembled the best-fit model iteratively using a stepwise procedure by rejecting/retaining the variables with the lowest/highest explanatory power one at a time (variables were discarded at $\alpha>0.05$, and retained otherwise). Then, we calculated the probability of shearwater occurrence for each surveyed grid cell in each year, using the final logistic model developed with the presence/absence data. We calculated the Linear Predictor (LP) using the constant and the variable coefficients from the best-fit model, and calculated the probability of shearwater occurrence predicted by the model (P) as follows: $\operatorname{Pr}=e^{\mathrm{LP}}\left(1+e^{\mathrm{LP}}\right)^{-1}$ (Crawley 1993).

Suitable habitat.- The receiver operator curve (ROC) plots provide a powerful approach to assess the performance of predictive ecological models based on presence/absence data (van Erkel and Pattynama 1998, Pearce and Ferrier 2000). This graphical method portrays the trade-off between the "sensitivity" (percentage of presence events correctly predicted) and "1 specificity" (percentage of the absence events correctly predicted) of the predictive model (van Erkel and Pattynama 1998, Boyce et al. 2002). Moreover, the area under the ROC curve (AUC) provides a metric of the predictive power of the model (Thuiller et al. 2003), which ranges between 0.5 (null predictive power, corresponding to the line of $45^{\circ}$ ) and 1 (a perfect model) (Boyce et al. 2002). We calculated the sensitivity and specificity of the model for a range of probabilities, and calculated the corresponding AUC value using the approach of Watkins (2000). We identified the probability value, which maximized the sensitivity and specificity of the model predictions using the ROC and AUC results (Pearce and Ferrier 2000, Boyce et al. 2002, Pearson et al. 2004). This threshold value was determined by the probability level where the sensitivity and the specificity curves intersected (Thuiller et al. 2003, Pearson et al. 2004).

\section{RESULTS \\ At-sea surveys}

We surveyed a total of 1409 10-min bins, which we aggregated into 680 grid cells during 95 survey days spanning the three years of our study (Table 2). Due to cloud cover, we discarded $16.6 \%$ of the surveyed grid cells with incomplete remote sensing information. We used the remaining grid cells $(n=567)$ for the analysis of shearwater occurrence, and those grids with shearwater presence $(n=140)$ for the analysis of density. We sighted 657 shearwaters over three years, with their maximum densities varying between 900 and 3453 birds per 100 $\mathrm{km}^{2}$ from year to year (Table 3). Overall, most of the shearwater sightings occurred between Cape Creus $\left(42.3^{\circ} \mathrm{N}\right)$ and the vicinity of Cape Palos $\left(38.0^{\circ} \mathrm{N}\right.$; Fig. 1).

\section{Spatial autocorrelation}

We found no evidence of significant spatial autocorrelation in the at-sea distribution of the Balearic Shearwater, neither for the occurrence nor the density data. These results indicated that the $9-\mathrm{km}$ grid cells yielded independent observations, and thus provided a

TABLE 2. Summary of seabird surveys showing the dates and survey effort during MEDITS cruises in 1999, 2000, and 2002.

\begin{tabular}{llcc}
\hline \hline Year & Cruise dates & $\begin{array}{c}\text { Surveyed area } \\
\left(\mathrm{km}^{2}\right)\end{array}$ & $\begin{array}{c}\text { Number of } \\
\text { grid cells }\end{array}$ \\
\hline 1999 & 4 May-4 June & 588.6 & 211 \\
2000 & 22 May-22 June & 571.6 & 163 \\
2002 & 11 May-13 June & 612.5 & 193 \\
Total & 95 days & 1772.6 & 567 \\
\hline
\end{tabular}

Note: Effort is expressed as both the area $\left(\mathrm{km}^{2}\right)$ and the number of $9-\mathrm{km}$ grid cells surveyed. 
TABLE 3. Summary of the Balearic Shearwater observations showing the total number of birds sighted, the number and proportion of occurrences, and the maximum density during each survey year.

\begin{tabular}{lccc}
\hline \hline Year & $\begin{array}{c}\text { Number } \\
\text { recorded }\end{array}$ & Occurencet & $\begin{array}{c}\text { Maximum density } \\
\left.\text { (birds/100 km }{ }^{2}\right)\end{array}$ \\
\hline 1999 & 387 & $56(26.5 \%)$ & 3453 \\
2000 & 175 & $37(22.7 \%)$ & 1675 \\
2002 & 95 & $47(24.3 \%)$ & 900 \\
Total & 657 & $140(24.7 \%)$ & \\
\hline
\end{tabular}

Note: Occurrence and density statistics are derived from the 9-km grid cells used for analysis.

$\dagger$ "Occurence" is the number of grids where shearwaters are present. Numbers in parentheses are the percentages of grids where shearwaters are present.

suitable spatial scale of analysis (Fig. 2). Both the occurrence and density correlograms did not show significant patterns. However, the occurrence correlogram suggested some degree of aggregation up to fairly large spatial scales $(54-63 \mathrm{~km})$ in 1999 and 2000 and at a smaller spatial scale $(18-27 \mathrm{~km})$ in 2002 . Overall, the shearwater distribution pattern seemed more spatially constrained in 2000, with larger positive Moran's I values at smaller lags $(9-54 \mathrm{~km})$ and negative values at larger lags $(>90 \mathrm{~km})$. Conversely, all Moran's $I$ values were positive in 1999 and 2002 (Fig. 2a). For the density data, all the Moran's $I$ values were close to 0 , suggesting a random distribution (Fig. 2b).

\section{Association to oceanographic habitats}

Balearic Shearwater occurrence.-The analysis of the presence/absence data identified seven significant predictor variables: distance to the nearest colony, distance to the shoreline, median depth, depth gradient, chl $a$ gradient, survey effort, and year of survey (Table 4). The interpretation of these results is based on the positive or negative sign of the estimated response coefficients, where a positive or negative sign is indicative of a greater or smaller probability of encountering a shearwater in a given grid cell, respectively. Therefore, the negative signs of the distance to the nearest colony and shoreline, the median depth, and depth gradient were suggestive of the distribution of the species along the Iberian continental shelf, close to the coast and to breeding colonies. The positive sign of the chl $a$ gradient estimate suggested the association of the Balearic Shearwater with oceanographic fronts indicative of productive coastal waters and river plumes. The positive association with the survey effort suggested that the greater the area surveyed within a $9-\mathrm{km}$ grid cell, the greater the probability of encountering a shearwater. Because the interannual effect was calculated relative to the last year of the study, the encounter probability was higher in 1999 and 2000 than in 2002 (see the null value of 2002 listed in Table 4). Altogether, the best-fit model explained $21 \%$ of the observed deviance. The goodness-of-fit test indicated

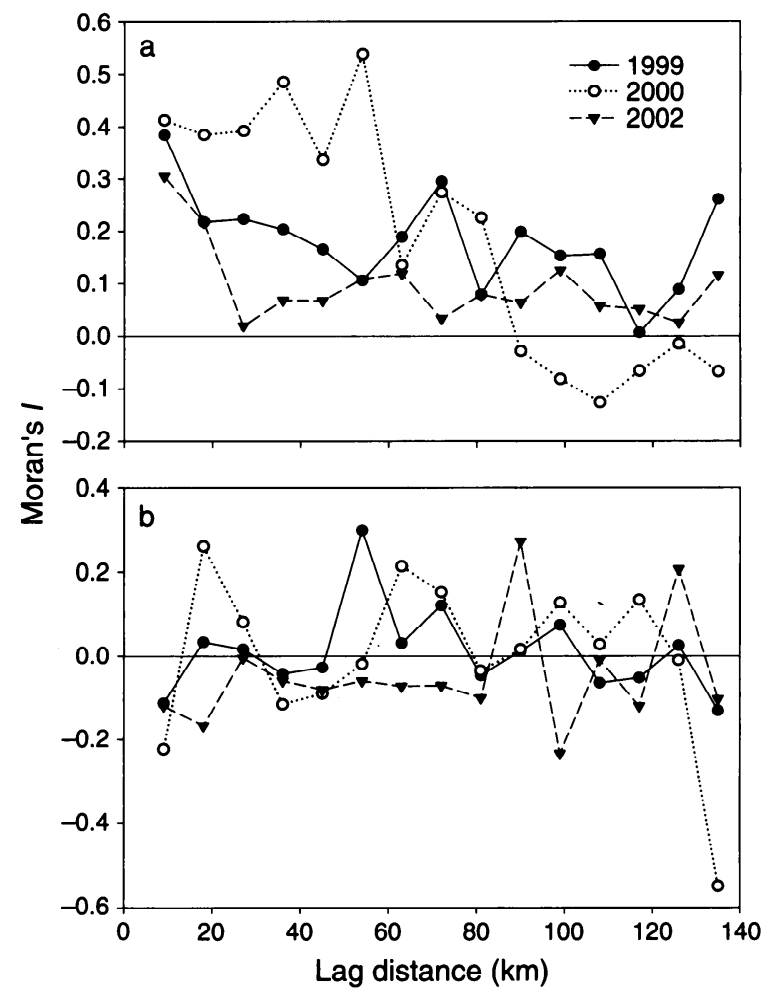

Fig. 2. Analysis of spatial autocorrelation: Moran's $I$ correlogram for Balearic Shearwater (a) occurrence and (b) density during the three years of surveys (1999-2002). The solid, horizontal line at zero represents a baseline showing no spatial pattern. All Moran's $I$ values were nonsignificant.

that the model performed well $\left(\chi^{2}=579.00, P=0.74, \mathrm{df}\right.$ $=558$ ).

Once we identified the significant variables, we represented the shearwater distribution and the underlying environmental datasets graphically using GIS. Balearic Shearwaters occurred predominantly around the Ebro Delta and in the vicinity of Cape La Nao, especially in 1999 and 2000. In 2002, the shearwaters

TABLE 4. Results of the generalized linear model (GLM) analysis of the Balearic Shearwater occurrence during the three years of this study.

\begin{tabular}{lccccc}
\hline \hline \multicolumn{1}{c}{ Variable } & $\begin{array}{c}\text { Estimate } \\
\text { parameter }\end{array}$ & SE & df & $\chi^{2}$ & $P$ \\
\hline Distance to colony & -0.007 & 0.001 & 1 & 33.82 & $<0.0001$ \\
Distance to shoreline & -0.026 & 0.012 & 1 & 4.69 & 0.030 \\
Median depth & -0.003 & 0.001 & 1 & 75.22 & $<0.0001$ \\
Depth gradient & -0.020 & 0.006 & 1 & 4.38 & 0.0364 \\
Chl $a$ gradient & 0.015 & 0.005 & 1 & 5.31 & 0.021 \\
Survey effort & 0.232 & 0.062 & 1 & 5.54 & $<0.019$ \\
Year (1999) & 0.639 & 0.269 & 2 & 7.39 & 0.025 \\
Year (2000) & 0.037 & 0.288 & & & \\
Year (2002) & 0.000 & 0.000 & & & \\
\hline
\end{tabular}

Notes: Only significant variables are shown. Degrees of freedom, chi-square, and signficance are given for the global contribution of the year effect and not for each specific year since the year variable is categorical. 

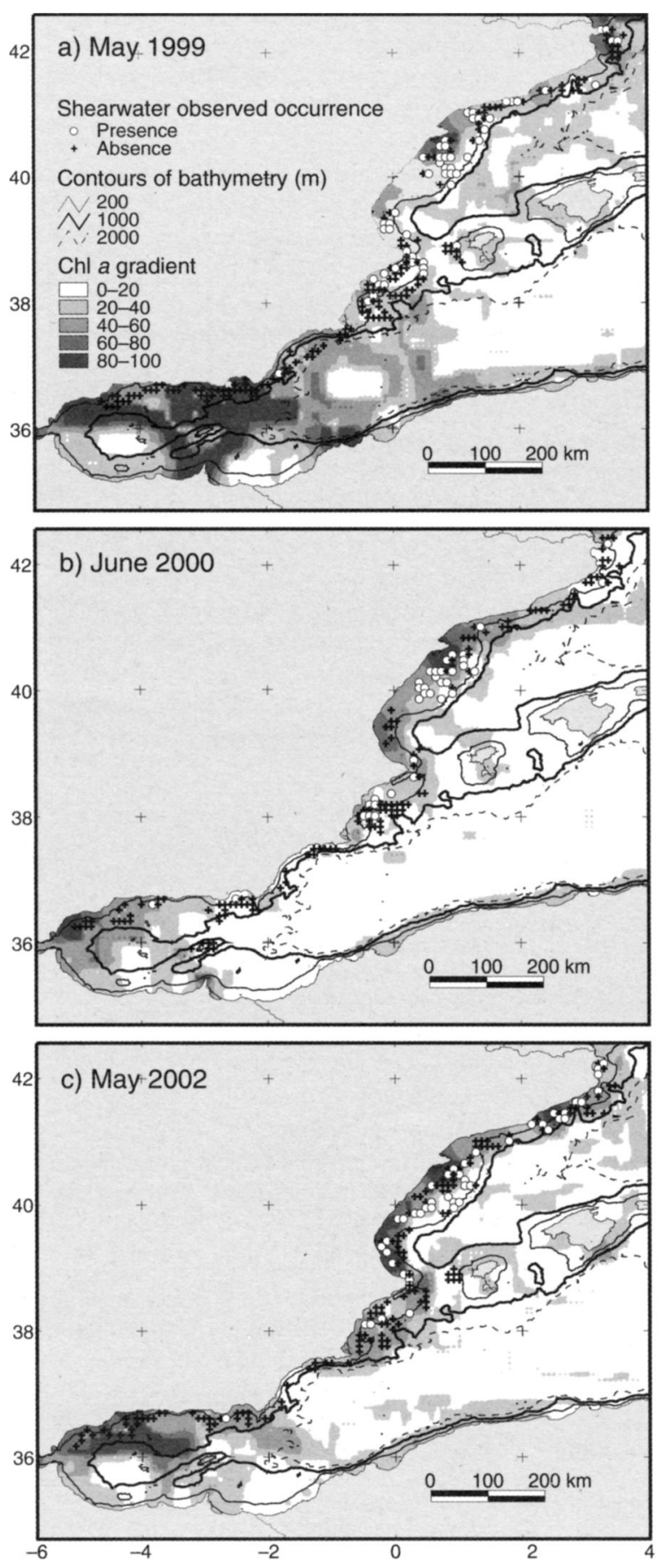

Fig. 3. Monthly average chl $a$ gradients and Balearic Shearwater occurrence in each grid cell in (a) May 1999, (b) June 2000, and (c) May 2002.

showed a more widely scattered pattern, with sightings from Cape Creus to Cape Palos (Fig. 3). We superimposed the shearwater distributions over the average chl $a$ gradients for each year using the monthly data from those months which better matched the temporal windows of the annual surveys: May (1999 and 2002) and June (2000) (cf. Table 2). We used the chl $a$ monthly average data only for mapping because they provided a more complete (i.e., cloud-free) spatial coverage of the study area. However, the habitat-use models used the finer-scale satellite imagery exclusively (see Methods).

Testing model accuracy and predictive power.-We obtained an AUC value of $0.795 \pm 0.006$ ( \pm SE; Fig. 4a), which was indicative of a good model performance (Swests 1988). The model accurately classified $71.4 \%$ of the presences and $72.6 \%$ of the absences of Balearic Shearwaters in 9-km grid cells. When we intersected the sensitivity and specificity curves, we identified a probability threshold of 0.3 (Fig. 4b). Thus, we considered those $9-\mathrm{km}$ grid cells where the predicted encounter probability exceeded 0.3 as the suitable habitat for the Balearic Shearwater. We generated maps of suitable habitat for each year, extending the area of interest to the northwestern African coast and including the breeding colonies in the Balearic archipelago (Fig. 5). We used the seven significant variables identified by the model to recalculate occurrence probabilities within this expanded area for each year. From the centroid of each
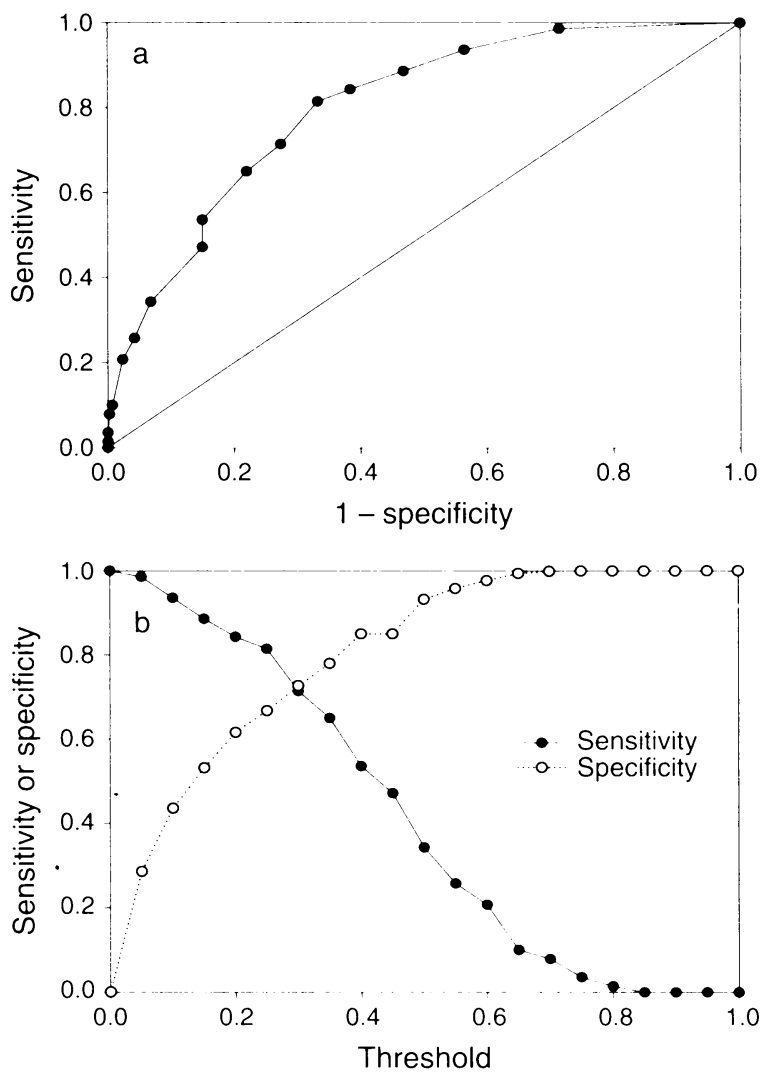

FIG. 4. Receiver operator curves (ROC) showing the tradeoffs when (a) the sensitivity is plotted vs. 1 - specificity, where the 1:1 line represents the expected probabilities if shearwaters were randomly distributed, and (b) the sensitivity and the specificity are calculated for each probability level to identify the suitable oceanographic habitat threshold $(\mathrm{Pr}=0.3$ in this case) (see Methods: Data analysis: Suitable habitat). 


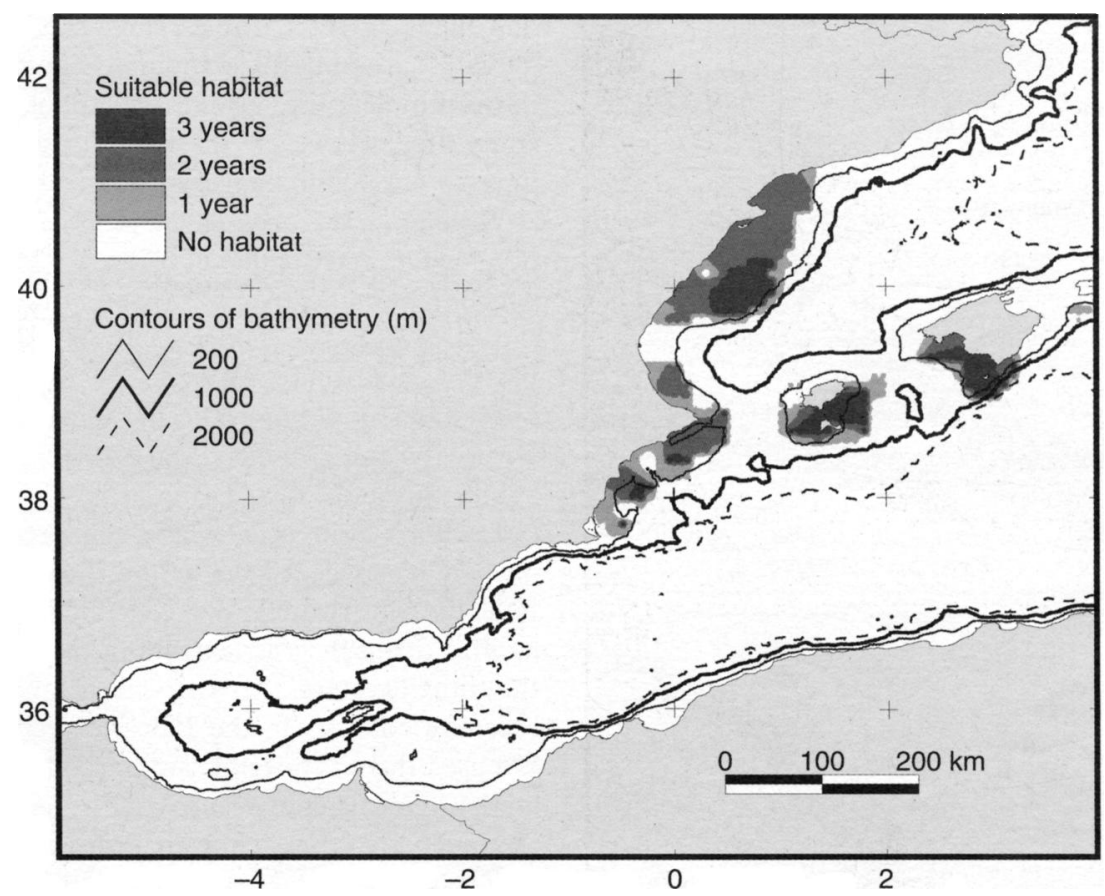

FIG. 5. Predicted suitable oceanographic habitat of the Balearic Shearwater modeled using three years of data $(1999,2000$, and 2002) and the threshold value of $\operatorname{Pr}=0.3$ (see Methods: Data Analysis: Model building). Each 9-km grid cell is color coded to show that it was identified as suitable habitat in one year (light gray), two years (medium gray), or three years (dark gray).

grid cell we computed the four variables that did not vary between years: distance to the nearest colony, distance to the shoreline, median depth, and depth gradient. To account for biases in survey effort, we calculated an average survey effort for the entire study period and applied that same value to all the grid cells. However, the monthly average values of the chl $a$ gradients and the year coefficients varied over time, driving the interannual variability in the location and extent of the suitable oceanographic habitat.

For the entire study period (1999-2002), the suitable oceanographic habitat included, in general terms, two areas in the Iberian continental shelf: the Ebro Delta area in the north and Cape La Nao in the south (latitudinal limit of $38.0^{\circ} \mathrm{N}$ ); and waters close to the breeding colonies at the Balearic archipelago. These

TABLE 5. Results of generalized linear model (GLM) analysis of the Balearic Shearwater density during the three years of this study.

\begin{tabular}{|c|c|c|c|c|c|}
\hline Variable & $\begin{array}{c}\text { Estimate } \\
\text { parameter }\end{array}$ & SE & $\mathrm{df}$ & $\chi^{2}$ & $P$ \\
\hline Chl $a$ median & 287.490 & 118.490 & 1 & 6.88 & 0.009 \\
\hline Survey effort & -48.204 & 15.978 & 1 & 8.90 & 0.003 \\
\hline Year (1999) & 193.622 & 73.868 & 2 & 6.79 & 0.034 \\
\hline Year (2000) & 82.693 & 81.557 & & & \\
\hline Year (2002) & 0.000 & 0.000 & & & \\
\hline
\end{tabular}

Note: Only significant variables are shown. Degrees of freedom, chi-square, and significance are given for the global contribution of the year effect and not for each specific year since the year variable is categorical. areas were classified as suitable shearwater habitat in at least two of the three survey years (Fig. 5).

Balearic Shearwater density.- The analysis of shearwater densities identified three significant predictor variables: median chl $a$, survey effort, and year (Table 5). The positive effect of median chl $a$ suggested that shearwaters were more abundant in highly productive waters. The survey effort revealed a sampling bias, with apparent shearwater densities within a grid cell diminishing with increasing survey area. Thus, shearwater sightings in grids with low survey effort tended to yield higher apparent density values. Finally, the year effect suggested that shearwater densities were higher during the first two years of the study $(1999,2000)$ than in 2002. Altogether, the best-fit model explained $15 \%$ of the observed deviance.

To illustrate the spatial distribution of shearwater aggregations, we plotted their density over the extent of different productivity regimes (Kahru and Mitchell 2000), defined using the monthly averages of median chl $a$ for each year separately (Fig. 6). The study area was characterized by a general mesotrophic regime (intermediate productivity). Some continental shelf locations were annually characterized by eutrophic (high nutrient) and some highly enriched areas. The area north of Cape Creus was highly productive in 1999, and the area around the Ebro Delta was characterized by elevated chl $a$ concentrations in 2000 and 2002 (Fig. 6).

The observed maximum values of shearwater density diminished over the study period (Table 3 ) and the 

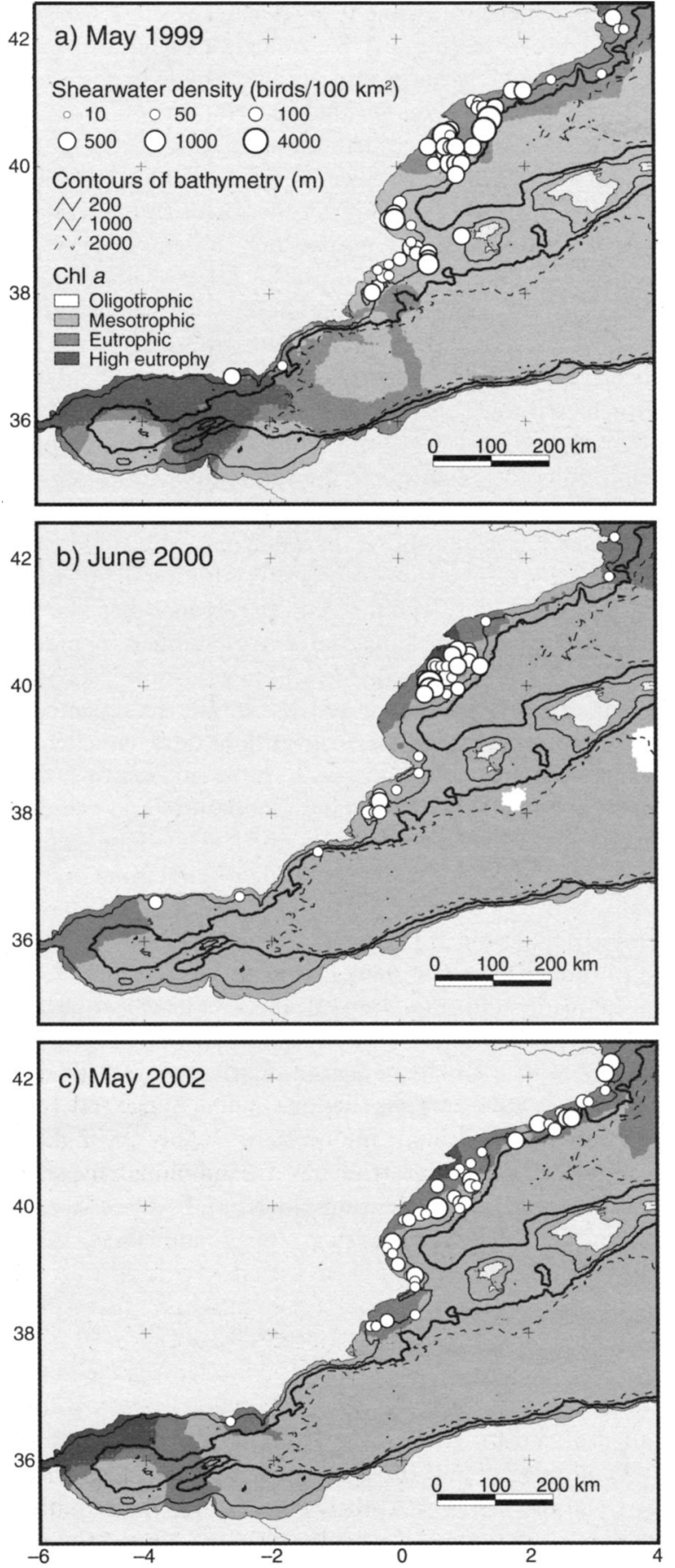

Fig. 6. Category of average monthly chl $a\left(\mathrm{mg} / \mathrm{m}^{3}\right)$ and observed Balearic Shearwater density within each $9-\mathrm{km}$ grid cell in (a) May 1999, (b) June 2000, and (c) May 2002. White circles indicate shearwater presence, with circle size being proportional to Balearic Shearwater density (birds/100 $\mathrm{km}^{2}$ ).

distribution patterns displayed noticeable interannual variability (Fig. 6). In 1999, two main areas of shearwater aggregations were identified, in both cases associated with mesotrophic conditions. The area around the Ebro Delta supported the highest densities, while the area around Cape La Nao was characterized by lower densities (Fig. 6a). In 2000, shearwaters were more strongly concentrated off the Ebro Delta, associated with the highest (highly eutrophic) chl $a$ levels (Fig. 6b). However, in 2002, shearwaters were widely distributed across the Iberian continental shelf from Cape Creus to the latitudinal limit of $38.0^{\circ} \mathrm{N}$. We did not identify any areas of dense foraging aggregations, even though the Ebro Delta region registered the highest chl $a$ levels in 2002 .

\section{Discussion}

\section{Oceanographic habitat of the Balearic Shearwater}

Although the Mediterranean is considered an oligotrophic sea, local ocean productivity is considerably variable in time and space (Estrada 1996, Agostini and Bakun 2002, Arnau et al. 2004). For instance, the remotely-sensed chl $a$ values documented in the study area were generally characteristic of a mesotrophic regime (Kahru and Mitchell 2000), even though the highly productive areas of the Ebro Delta and the Alboran Sea gyres were characterized by highly enriched phytoplankton pigment concentrations. The foraging range of the Balearic Shearwater during the chickrearing season mainly comprised the Iberian continental shelf between $42.3^{\circ} \mathrm{N}$ and $38.0^{\circ} \mathrm{N}$. These analyses revealed that shearwaters were present in shallow shelf and coastal waters characterized by frontal systems in areas closer to their breeding colonies. Within this larger foraging range, shearwaters were most numerous in the highly productive waters with elevated chl $a$ concentrations around the Ebro Delta (especially in 2000) and the area extending to the south of Cape La Nao. These results suggested that the shearwaters were responding to diverse oceanographic processes. They were likely aggregating off the Ebro Delta in response to plumes of higher productivity associated with the spring-summer input of surface nutrients from the Ebro River, during a period of weak vertical mixing (Salat et al. 2000). The shearwater sightings around Cape Creus could also be explained by the presence of mesoscale oceanographic features (Arnau et al. 2004) and submarine canyons (Palanques et al. 2005) acting to increase localized productivity and aggregate prey. Both the distribution and abundance patterns showed substantial interannual variability, which was likely associated with the influence of some additional explanatory variables not included in the models. Namely, year-to-year changes in the discharge of the Ebro River, shifts in the stocks of small pelagic fish, and spatiotemporal variability of the fishing effort and fishery discards, as well as variability of survey effort, could influence shearwater distribution patterns (Lloret et al. 2001, Agostini and Bakun 2002, Arnau et al. 2004).

The oceanographic habitat model results matched the foraging range described by the observed data, and also identified the waters close to the breeding colonies in the 
Balearic Islands as potentially suitable habitat for the Balearic Shearwater. Conversely, the Alboran Sea was not identified as suitable shearwater habitat, although it was characterized by high primary productivity associated with high chl $a$ gradients and hydrographic fronts (Millot and Taupier-Letage 2004). We hypothesize that the large distance between the breeding colonies and the Alboran Sea make these productive waters unsuitable for central place foraging shearwaters.

Our results agree with previous studies, which have underscored the near-shore distribution of the Balearic Shearwater and its tendency to occur in the vicinity of the Ebro Delta (Abelló and Oro 1998, Arcos and Oro 2002, Abelló et a1. 2003). Yet, to our knowledge, this is the first time that a significant association of Balearic Shearwaters and frontal systems has been documented on the basis of quantitative analyses of oceanographic variables. The association of this endangered species with dynamic oceanographic habitats, defined by the extent of hydrographic features (e.g., frontal systems, productive river plumes), has important implications for its management and conservation.

In particular, frontal regions where adjacent water masses of different properties come together are often characterized by convergence zones which aggregate marine organisms, including seabirds and their zooplankton and fish prey (LeFevre 1986, Franks et al. 1992, Hunt et al. 1996). Aggregations of upper-trophiclevel organisms are presumably the consequence of the tight coupling of predator-prey interactions at frontal systems, due to either enhanced aggregation or availability of subsurface prey to diving predators (Schneider 1993). Several previous studies have revealed dense aggregations $\left(100-1000 \mathrm{birds} / \mathrm{km}^{2}\right)$ of diving shearwaters at narrow $(\sim 10 \mathrm{~km})$ tidal fronts characterized by elevated and persistent productivity within broad continental shelves (Hunt et al. 1996, Begg and Reid 1997). While Balearic Shearwaters did not aggregate into such dense flocks, we documented intense aggregations $\left(10-40\right.$ birds $\left./ \mathrm{km}^{2}\right)$ in the vicinity of the Ebro Delta (Table 3, Fig. 6).

As part of our analysis, we did not detect any significant association of shearwaters with trawlers, suggesting that while fishery discards make an important contribution to the energetic requirements of the species (Arcos and Oro 2002), they do not influence their distribution over large spatial scales (tens to hundreds of kilometers; cf. Skov and Durinck 2001). Thus, we hypothesize that discards represent a quantitatively important, yet secondary, foraging resource, taken opportunistically in the absence of alternative prey (cf., Arcos et al. 2006). In this case, oceanographic conditions were the major determinant of the Balearic Shearwater distribution, rather than trawl fishery distribution, as has been previously suggested for other opportunistic scavenging seabirds in the North Sea (Camphuysen and Garthe 1997). Nevertheless, since the highly productive areas used by the shearwaters also sustain demersal trawling fleets (Demestre et al. 1988), it is difficult to tease apart the influence of natural (e.g., spawning aggregations) and anthropogenic (e.g., fishery discards) food sources on their distributions.

One of the main contributions of this study to the ecology of the Balearic Shearwater is the ability to map potentially suitable habitat in other areas of the western Mediterranean not surveyed using ship-based surveys. However, this approach must be taken with caution because it assumes that the habitat associations we defined for the study area can be extrapolated to other unsurveyed areas, such as the Gulf of Lions and the North African Coast. This example illustrates the need for repeated surveys during contrasting oceanographic conditions to validate habitat suitability models developed for a specific area (Forney 2001, Raymond and Woehler 2003), and shows the value of predictive models as an exploratory tool to identify additional potential habitats of highly endangered species in other poorly studied areas. Suitable habitat areas identified by model results could be targeted for exploratory ship-based and aerial surveys. In both cases, the ability to repeatedly survey protected species distributions and concurrent oceanographic conditions over different seasons and years is critical for developing, validating, and refining habitat suitability models. In particular, these standardized surveys are critical to identifying time trends both between seasons (early-late spring) and across years (population trends).

Future research should also focus on obtaining a mechanistic understanding of the small-scale interactions between local oceanographic conditions, prey distribution, and the aggregation patterns and behavior of Balearic Shearwaters within the high-use foraging grounds identified in the present study. Promising avenues entail satellite tracking of individual foragers and small-scale surveys along the frontal systems where the species concentrates (e.g., Begg and Reid 1997, Hyrenbach et al. 2002).

\section{Conservation measures: implementation of marine protected areas}

The degree of aggregation and the habitat associations of far-ranging seabirds greatly influence their susceptibility to anthropogenic threats, such as longline bycatch and oil spills, and the potential use of marine protected areas (MPAs) to mitigate those threats (Anderson et al. 2003, Hyrenbach et al. 2006). Seabirds are particularly susceptible to anthropogenic impacts at certain time periods (e.g., breeding season) and localities (e.g., foraging grounds) when/where they aggregate in dense concentrations (Hunt et al. 1996, Huettmann and Diamond 2000). Similarly, the feasibility and effectiveness of specific management practices depend on both the spatial extent and the degree of aggregation of the protected species and the threats in question.

Nevertheless, given its delicate status, marine zoning measures may greatly benefit the conservation of the 
Balearic Shearwater by extending protective measures beyond the breeding colonies. In particular, MPAs and time-area closures may help mitigate fisheries bycatch, impacts from wind farms, and the risk of catastrophic oil spills. Habitat models could guide the design of effective, spatially explicit conservation measures by characterizing those areas of special interest for conservation such as foraging areas and movement corridors (e.g., BirdLife International 2004). In principle, marine zoning strategies based on geographically fixed features (e.g., seamounts, shelf-breaks, submarine canyons) are much more conducive to implementation, because their boundaries are defined by the extent of static depth contours. Dynamic MPA boundaries would be much more difficult, but not impossible, to implement (Hyrenbach et al. 2000, Norse et al. 2005). However, there is a clear need to develop such an MPA model, and marine zoning measures defined by seasonal and interannual changes in water mass distributions have already been used to mitigate fisheries bycatch (e.g., Nagao et al. 1993, NOAA 2002).

Following the model of a core-buffer MPA, we envision the following marine zoning approach to protect Balearic Shearwaters during the breeding season. Areas of dense aggregations could serve as the core regions deserving elevated protection. Namely, the area of influence by the Ebro River discharge and Cape La Nao region would be ideal candidates for stringent protective measures, including prohibition of oil tanker traffic and the adoption of adequate measures to help shearwaters to avoid fisheries bycatch (Arcos and Oro 2004, Arcos et al. 2006). The dynamic nature and interannual variability of fronts raises the necessity of the periodical revision of their geographic extension. Nevertheless, these features could be monitored remotely using satellite imagery and certain areas of likely habitat could be delineated on the basis of the probability of occurrence of these frontal systems. Other areas identified by the modeling of suitable habitat (e.g., areas surrounding the breeding colonies) should be surveyed to evaluate their importance as foraging grounds for the species, and could presumably be integrated into an MPA network linking the distant foraging grounds identified in the Iberian continental shelf (Roberts et al. 2001).

In addition to the core foraging grounds, other more diffuse protective measures could be implemented within a larger buffer region delineated by the range of the species. Namely, a compulsory fishery observer program to record potential bycatch in longline fisheries, and the study of potential impacts of wind farms would apply to the continental shelf region, especially in the vicinity of the Ebro Delta. Currently, a marine wind farm is planned just a few kilometers off the Ebro Delta.

While we acknowledge that effective conservation of the Balearic Shearwater may require the implementation of protective measures throughout the life cycle of the species, we recognize that MPAs identified in this study (restricted to the chick-rearing period) may not be feasible or effective during the post-breeding and juvenile dispersal stages. Thus, we advocate the judicious use of marine zoning strategies for MPA identification outside the breeding season in conjunction with other non-site-specific management measures (e.g., bycatch mitigation and oil spill prevention programs), when the species disperses into the Western Mediterranean and the North Atlantic. Ultimately, non-sitespecific management measures should always complement site-specific measures (MPAs), even when a welldesigned and thorough MPA network is implemented.

\section{ACKNOWLEDGMENTS}

We wish to thank to all participants in the MEDITS series cruises on board B/O "Cornide de Saavedra," both scientists and crew, for all their help and support. M. Ruiz helped with GIS, M. Palmer and D. Serrano with statistical analyses, and M. M. Fletxas with the oceanographic interpretation of the results. J. M. Igual and two anonymous referees made useful comments for improving drafts of this manuscript. This study was funded by EC project DISCBIRD (QLRT-2000-00839), Spanish Ministries of Science and Technology (BOS200301960) and of the Environment (ref. 024A/2002). M. Louzao was supported by a fellowship of Conselleria de Innovació, Hisenda i Economia (Govern de les Illes Balears). K. D. Hyrenbach was supported by the.OBIS-SEAMAP program at Duke University, a Census of Marine Life component funded by the Alfred P. Sloan Foundation. J. M. Arcos was supported by FI/FIAP and BE fellowships from the Catalan Government (DURSI) during the fieldwork and by a Marie Curie Individual Fellowship (QLK5-CT2002-51518) and Marie Curie project MARIBA (MERG-CT-2004-022065) afterwards.

\section{Literature Cited}

Abelló, P., J. M. Arcos, and L. Gil de Sola. 2003. Geographical patterns of seabird attendance to a research trawler along the Iberian Mediterranean coast. Scientia Marina 67(S2):69-75.

Abelló, P., and G. Guerao. 1999. Temporal variability in the vertical and mesoscale spatial distribution of crab Megalopae (Crustacea: Decapoda) in the Northwestern Mediterranean. Estuarine, Coastal and Shelf Science 49:129-139.

Abelló, P., and D. Oro. 1998. Offshore distribution of seabirds in the Northwestern Mediterranean in June 1995. Colonial Waterbirds 21:422-426.

Agostini, V. N., and A. Bakun. 2002. 'Ocean triads' in the Mediterranean Sea: physical mechanisms potentially structuring reproductive habitat suitability (with example application to European anchovy, Engraulis encrasicolus). Fisheries Oceanography 11:129-142.

Anderson, D. J., K. P. Huyvaert, D. R. Wood, C. L. Gillikin, B. J. Frost, and H. Mouritsen. 2003. At-sea distribution of Waved Albatrosses and the Galápagos Marine Reserve. Biological Conservation 110:367-373.

Arcos, J. M., M. Louzao, and D. Oro. 2006. Fisheries ecosystem impacts and management in the Mediterranean: seabirds point of view. Pages $587-595$ in J. Nielsen, J. Dodson, K. Friedland, T. Harmon, N. Hughes, J. Musick, and E. Verspoor, editors, Proceedings of the Fourth World Fisheries Congress: reconciling fisheries with conservation. American Fisheries Society, Bethesda, Maryland, USA.

Arcos, J. M., E. Massutí, P. Abelló, and D. Oro. 2000. Fish associated with floating drifting objects as a feeding resource for Balearic Shearwaters Puffinus mauretanicus during the breeding season. Ornis Fennica 77:177-182.

Arcos, J. M., and D. Oro. 2002. Significance of fisheries discards for a threatened Mediterranean seabird, the Balearic 
Shearwater Puffinus mauretanicus. Marine Ecology Progress Series 239:209-220.

Arcos, J. M., and D. Oro. 2004. Pardela Balear, Puffinus mauretanicus. Pages 46-50 in A. Madroño, C. González, and J. C. Atienza, editors. Libro rojo de las aves de España. Dirección general para la biodiversidad-SEO/BirdLife, Madrid, Spain.

Arnau, P., C. Liquete, and M. Canals. 2004. River mouth plume events and their dispersal in the Northwestern Mediterranean Sea. Oceanography 17:23-31.

Baillie, J. E. M., C. Hilton-Taylor, and S. N. Stuart. 2004. IUCN Red List of threatened species. A global species assessment. IUCN, Gland, Switzerland and Cambridge, UK.

Bearzi, G., R. R. Reeves, G. Notarbartolo-Di-Sciara, E. Politi, A. Cañadas, A. Frantzis, and B. Mussi. 2003. Ecology, status and conservation of short-beaked common dolphins Delphinus delphis in the Mediterranean Sea. Mammal Review 33: 224-252.

Begg, G. S., and J. B. Reid. 1997. Spatial variation in seabird density at a shallow sea tidal mixing front in the Irish Sea. ICES Journal of Marine Science 54:552-565.

Bertrand, J. A., L. Gil de Sola, C. Papaconstantinou, G. Relini, and A. Souplet. 2002. The general specifications of the MEDITS surveys. Scientia Marina 66:9-17.

BirdLife International. 2004. Tracking ocean wanderers: the global distribution of albatrosses and petrels. Results from the Global Procellariiform Tracking Workshop, 1-5 September, 2003, Gordon's Bay, South Africa. Cambridge, UK.

Boyce, M. S., P. R. Vernier, S. E. Nielsen, and F. K. A. Schmiegelow. 2002. Evaluating resource selection functions. Ecological Modelling 157:281-300.

Camphuysen, C. J., and S. Garthe. 1997. An evaluation of the distribution and scavenging habits of northern fulmars (Fulmarus glacialis) in the North Sea. ICES Journal of Marine Science 54:654-683.

Cañadas, A., R. Sagarminaga, R. De Stephanis, E. Urquiola, and P. S. Hammond. 2005. Habitat preference modelling as a conservation tool proposals for marine protected areas for cetaceans in southern Spanish waters. Aquatic Conservation: Marine and Freshwater Ecosystems 15:495-521.

Cardona, L., M. Revelles, C. Carreras, M. San Felix, M. Gazo, and A. Aguilar. 2005. Western Mediterranean immature loggerhead turtles: habitat use in spring and summer assessed through satellite tracking and aerial surveys. Marine Biology 147:583-591.

Crawley, M. J. 1993. GLIM for ecologists. Blackwell Scientific, Oxford, UK.

Demestre, M., J. Lleonart, P. Martín, L. Recasens, and P. Sánchez. 1988. La pesca en Cataluña. FAO Rapport Pêches 395:101-103.

De Segura, A. G., J. Tomas, S. N. Pedraza, E. A. Crespo, and J. A. Raga. 2003. Preliminary patterns of distribution and abundance of loggerhead sea turtles, Caretta caretta, around Columbretes Islands Marine Reserve, Spanish Mediterranean. Marine Biology 143:817-823.

EEC (European Economic Community). 1979. Council Directive 79/409/EEC of 2 April 1979 on the conservation of wild birds. Page 1 in Official Journal L 103, 25/04/1979. European Economic Community, Brussels, Belgium.

EEC (European Economic Community). 1992. Council Directive $92 / 43 /$ EEC of 21 May 1992 on the conservation of natural habitats and of wild fauna and flora. Page 7 in Official Journal L 206, 22/07/1992. European Economic Community, Brussels, Belgium.

Estrada, M. 1996. Primary production in the northwestern Mediterranean. Scientia Marina 60(S2):55-64.

Font, J., J. Salat, and J. Tintoré. 1988. Permanent features in the circulation of the Catalan Sea. Oceanologia Acta 9:51-57.

Forney, K. A. 2000. Environmental models of cetacean abundance: reducing uncertainty in population trends. Conservation Biology 14:1271-1286.
Franks, P. J. S. 1992. Swim or sink: accumulation of biomass at fronts. Marine Ecology Progress Series 82:1-12.

Gerber, L. R., K. D. Hyrenbach, and M. A. Zacharias. 2005. Do the largest reserves protect whales or whalers? Science 307:525-526.

Halpern, B. S. 2003. The impact of marine reserves: do reserves work and does reserve size matter? Ecological Applications 13:S117-S137.

Heinemann, D. 1981. A rangefinder for pelagic bird censusing. Journal of Wildlife Management 45:489-493.

Hooker, S. B., and C. R. McClain. 2000. The calibration and validation of SeaWiFS data. Progress in Oceanography 45: 427-465.

Hooker, S. K., H. Whitehead, and S. Gowans. 1999. Marine protected area design and the spatial and temporal distribution of cetaceans in a submarine canyon. Conservation Biology 13:592-602.

Hooker, S. K., and L. R. Gerber. 2004. Marine reserves as a tool for ecosystem-based management: the potential importance of megafauna. BioScience 54:27-39.

Houde, E. 2001. Marine protected areas: tools for sustaining ocean ecosystems. National Academy Press, Washington, D.C., USA.

Huettmann, F., and A. W. Diamond. 2000. Seabird migration in the Canadian northwest Atlantic Ocean: moulting locations and movement patterns of immature birds. Canadian Journal of Zoology 78:624-647.

Hunt, G. L., Jr., K. O. Coyle, S. Hoffman, M. B. Decker, and E. N. Flint. 1996. Foraging ecology of Short-tailed Shearwaters near the Pribilof Islands, Bering Sea. Marine Ecology Progress Series 141:1-11.

Hurlbert, S. H. 1984. Pseudoreplication and the design of ecological field experiments. Ecology 54:187-211.

Hyrenbach, K. D., P. Fernández, and D. J. Anderson. 2002. Oceanographic habitats of two sympatric North Pacific albatrosses during the breeding season. Marine Ecology Progress Series 233:283-301.

Hyrenbach, K. D., K. A. Forney, and P. K. Dayton. 2000. Marine protected areas and ocean basin management. Aquatic Conservation 10:437-458.

Hyrenbach, K. D., C. Keiper, S. G. Allen, D. J. Anderson, and D. G. Ainley. 2006. Use of national marine sanctuaries by far-ranging predators: commuting flights to the California Current System by breeding Hawaiian albatrosses. Fisheries Oceanography 15:95-103.

James, M. C., C. A. Ottensmeyer, and R. A. Myers. 2005. Identification of high-use habitat and threats to leatherback sea turtles in northern waters: new directions for conservation. Ecology Letters 8:195-201.

Kahru, M. 2000. Windows Image Manager-Image display and analysis program for Microsoft Windows with special features for satellite images. 〈http://wimsoft.com)

Kahru, M., and B. G. Mitchell. 2000. Influence of the 1997-98 El Niño on the surface chlorophyll in the California Current. Geophysical Research Letters 27:2937-2940.

LeFevre, J. 1986. Aspects of the biology of frontal systems. . Advances in Marine Biology 23:163-299.

Lloret, J., J. Lleonart, I. Solé, and J. M. Fromentin. 2001. Fluctuations of landings and environmental conditions in the north-western Mediterranean Sea. Fisheries Oceanography 10:33-50.

Longhurst, A. 1998. Ecological geography of the sea. Academic Press, San Diego, California, USA.

Louzao, M., J. M. Igual, M. McMinn, J. A. Aguilar, R. Triay, and D. Oro. 2006. Small pelagic fish, trawling discards and breeding performance of the critically endangered Balearic Shearwater: improving conservation diagnosis. Marine Ecology Progress Series, in press.

Manly, B. F. J. 1994. Multivariate statistical methods. Second edition. Chapman and Hall, New York, New York, USA. 
Millot, C. 1999. Circulation in the Western Mediterranean Sea. Journal of Marine Systems 20:423-442.

Millot, C., and I. Taupier-Letage. 2005. Circulation in the Mediterranean Sea. Pages 1-30 in A. Saliot, editor. The Mediterranean Sea: the handbook of environmental chemistry. Volume 5: water pollution. Springer-Verlag, New York, New York, USA.

Nagao, K., S. Ota, and J. Hirono. 1993. Regulation of the Japanese high seas driftnet fisheries. International North Pacific Fisheries Commission Bulletin 53:39-44.

NGDC (National Geophysical Data Center). 1998. Data Announcement 88-MGG-02, digital relief of the surface of the Earth. Boulder, Colorado, USA. (www.ngdc.noaa.gov/ $\mathrm{mgg} / \mathrm{global} / \mathrm{seltopo}$.html

NOAA. 2002. Taking of threatened or endangered species incidental to commercial fishing operations. Federal Register 67:59243-59245.

Norse, E. A., L. B. Crowder, K. Gjerde, K. D. Hyrenbach, C. Roberts, and M. E. Soulé. 2005. The potential for reserves as an ecosystem-based management tool in the open ocean. Pages 302-327 in E. A. Norse and L. B. Crowder, editors. Marine Conservation Biology. Island Press, Washington, D.C., USA.

Oro, D., J. S. Aguilar, J. M. Igual, and M. Louzao. 2004. Modelling demography and extinction risk in the endangered Balearic Shearwater. Biological Conservation 116:93-102.

Palanques, A., et al. 2005. General patterns of circulation, sediment fluxes and ecology of the Palamós (La Fonera) submarine canyon, northwestern Mediterranean. Progress in Oceanography 66:89-119.

Pearce, J., and S. Ferrier. 2000. Evaluating the predictive performance of habitat models developed using logistic regression. Ecological Modelling 133:225-245.

Pearson, R. G., T. P. Dawson, and C. Liu. 2004. Modelling species distributions in Britain: a hierarchical integration of climate and land-cover data. Ecography 27:285-298.

Pikitch, E. K., et al. 2004. Ecosystem-based fishery management. Science 305:346-347.

Planes, S., R. Galzin, A. Garcia Rubies, R. Goñi, J. G. Harmelin, L. Le Diréach, P. Lenfant, and A. Quetglas. 2000. Effects of marine protected areas on recruitment processes with special reference to Mediterranean littoral ecosystems. Environmental Conservation 27:126-143.

Raymond, B., and E. J. Woehler. 2003. Predicting seabirds at sea in the Southern Indian Ocean. Marine Ecology Progress Series 263:275-285.

Roberts, C. M., B. Halpern, S. R. Palumbi, and R. R. Warner. 2001. Designing marine reserve networks. Conservation Biology in Practice 2:10-17.

Ruiz, A., and R. Martí. 2004. La Pardela Balear. SEO/BirdLifeConselleria de Medi Ambient del Govern de les Illes Balears. Madrid, Spain.

Sabatés, A. 1996. Distribution pattern of larval fish populations in the Northwestern Mediterranean. Marine Ecology Progress Series 59:75-82.

Salat, J. 1996. Review of hydrographic environmental factors that may influence anchovy habitats in the northwestern Mediterranean. Scientia Marina 60(S2):21-32.
Salat, J., M. A. Garcia, A. Cruzado, A. Palanques, L. Arín, D. Gomis, J. Guillén, A. de León, J. Puigdefàbregas, J. Sospedra, and Z. R. Velásquez. 2002. Seasonal changes of water mass structure and shelf slope exchanges at the Ebro Shelf (NW Mediterranean). Continental Shelf Research 22: 327-348.

SAS Institute. 2000. SAS/STAT software: user's guide. Cary, North Carolina, USA.

Sawada, M. 1999. Rookcase: an Excel 97/2000 visual basic (VB) add-in for exploring global and local spatial autocorrelation. Bulletin of the Ecological Society of America 80:231-234.

Schneider, D. C. 1990. Spatial autocorrelation in marine birds. Polar Research 8:89-97.

Schneider, D. C. 1993. The role of fluid dynamics in the ecology of marine birds. Oceanography and Marine Biology: An Annual Review 29:487-521.

Schneider, D. C. 1997. Habitat selection by marine birds in relation to water depth. Ibis 139:175-178.

Skov, H., and J. Durinck. 2001. Seabird attraction to fishing vessels is a local process. Marine Ecology Progress Series 214: 289-298.

Sokal, R. R., and N. L. Oden. 1978. Spatial autocorrelation in biology. I. Methodology. Biological Journal of the Linnean Society 10:199-228.

Sokal, R. R., N. L. Oden, and B. A. Thomson. 1998. Local spatial autocorrelation in biological variables. Biological Journal of the Linnean Society 65:41-62.

Spear, L. B., L. T. Ballance, and D. G. Ainley. 2001. Response of seabirds to thermal gradients in the tropical Pacific: the thermocline versus the Equatorial Front. Marine Ecology Progress Series 219:275-289.

SPEA-SEO/BirdLife. 2005. Implementing N2000 in the marine environment. Marine IBAs: Lisbon-Vilanova conclusions. 〈http://www.seo.org/media/docs/Marine\%20IBAs\% 20Lisbon-Vilanova\%20conclusions.pdf $\rangle$

Swests, K. A. 1988. Measuring the accuracy of diagnostic systems. Science 240:1285-1293.

Tasker, M. L., P. H. Jones, T. Dixon, and B. F. Blake. 1984. Counting seabirds at sea from ships: a review of methods employed and a suggestion for a standardized approach. Auk 101:567-577.

Thuiller, W., J. Vayreda, J. Pino, S. Sabate, S. Lavorel, and C. Gracia. 2003. Large-scale environmental correlates of forest tree distributions in Catalonia (NE Spain). Global Ecology and Biogeography 12:313-325.

Van Erkel, A. R., and P. M. T. Pattynama. 1998. Receiver operating characteristic (ROC) analysis: basic principles and applications in radiology. European Journal of Radiology 27 : 88-94.

Watkins, M. W. 2000. An Excel program for calculating and graphing the Receiver Operating Characteristic (ROC). Ed and Psych Associates. State College, Pennsylvania, USA.

Williams, G., D. Pullan, I. Dickie, D. Huggett, and H. Mitchell. 2005. The European Birds Directive-safeguarding special places for people and wildlife. Royal Society for the Protection of Birds (RSPB), Sandy, Bedfordshire, UK.

Zar, J. H. 1999. Biostatistical analysis. Fourth edition. PrenticeHall, Upper Saddle River, New Jersey, USA. 